\title{
ANNE APPLEBAUM'S STRATEGY OF TELLING THE HISTORY OF INTERNATIONAL RELATIONS IN CENTRAL AND EASTERN EUROPE
}

Anne Applebaum was born in the United States, where she was educated and then continued her studies in the United Kingdom. Her moving to Poland was due to her journalism work. Early in her career, a quality education environment at Yale University and the London School of Economics influenced her identity as an American by birth. Her family contributed to the acquisition of perfect knowledge. Two prominent researchers and experts in the history of the USSR - Richard Pipes and Robert Conquest, impacted her choice of research topics.

The first impressed her with his studies on the political and military aspects of the USSR. The second initiated in the Western world professional discussion on Stalin's famine of 1932-1933. Due to this A. Applebaum mentioned them in an interview with the international intellectual magazine Ukraina Moderna (Modern Ukraine), which focuses on the modern history of Ukraine and Central and Eastern Europe. She calls Pipes and Conquest "my favourite historians," and explains that she was acquainted with them personally: "Both impressed me with their ability to write not only for the academic community, but also for a wide range of people - this is what I always try to do in my books" (Mattingly, 2018).

Another factor that led her to study the countries of the former Soviet Union was a trip from Kaliningrad to Odesa in 1990. She recalls, "She spent most of the trip in Ukraine." The result was A. Applebaum's first book, Between East and West: Across the Borderlands of Europe (Applebaum, 1994).

However, the most influential were socio-political changes in Central and Eastern Europe in the late 80 ties and the early 90 ties of the $20^{\text {th }}$ century. She believes that the events of 1989 had an intellectual impact and also determined her career orientation. In the light of her reminiscence: "I was most impressed by the collapse of Communism - that's when I felt the calling to journalism." (Mattingly, 2018).

The question arises how strongly A. Applebaum's journalistic engagement in telling the Central and Eastern Europe's past and presence influenced her perception and self-recognition. She was deeply immersed in local narratives and memories. Becoming someone who pursues to tell them to the Western audiences, she decided to change place of stay and settled down in Poland; it was necessary to combine historical research with journalism. Family circumstances also forced her to integrate into life in Poland. Knowledge of several languages, finding common ground among Polish society, as well as among British or American, put her close to other nations of this part of the world. 
All these circumstances allowed A. Applebaum to understand thoroughly Central and Eastern European identities. However, it does not mean that she has become someone 'in between' who is neither Anglo-Saxon, nor Central or Eastern European. In Central and Eastern European countries she remained a kind of outsider who was looking for knowledge about their specificity as it should be approached and translated to the A. Applebaum's cultural companions. She represented also the academic world and as a scholar studying social development was definitely determined to know the most about its heroes and antiheroes. And as a journalist who writes about profound changes abroad, she was doing as much as possible to understand the whole process well, approaching for example "a form of social behaviour" (Titscher, 2000: 146) of people changing the course of history, as it happened in Central and Eastern Europe in the $20^{\text {th }}-21^{\text {st }}$ centuries.

Timothy Snyder considers that studying "transformations of old elites" can bring a researcher to deep understanding of a world which is not her or his. This activity is able not only to deliver a lot of cognitive satisfaction but also a desire to become a part of other's history (Snyder, 2003: 130). We can estimate that with the beginning of the study of foreign history, another country, another social order, a kind of intellectualresearcher's transformation takes place. Her or his interest tends to understand the identities, which has been shaping for a long time beyond the scope of her or his consciousness. At this time, there is a partial retelling of historical events from one era to another.

A. Applebaum's research revives the historical memory of the inhabitants of Central and Eastern Europe, their national and cultural identities. Referring to her works and self-identifications we can assume that struggling to comprehend the region she remains under the influence of an Italian researcher, Andrea Graziosi, who studied the state of Central and Eastern Europe after World War II, or as he called it after the "great European war" (Graziosi, 2001: 282). A. Graziosi believes that the events in the East had tragic consequences due to the redrawing of borders, the adoption of the Soviet example of development, and "the importation of tyrannical forms that imitated the Muscovite model" (Graziosi, 2001: 280). This happened "as a result of the punitive policy pursued by the Soviet Union on the basis of the principle of collective responsibility" (Graziosi, 2001: 280). A. Graziosi's conclusions seem to have served to some extent as a starting catalyst for A. Applebaum's research, as she refers to his works in her book, Red Famine: Stalin's War on Ukraine (Applebaum, 2017). But the period of European history studied by her reveals the tragedy of the $20^{\text {th }}$ century much more deeply and richly to the $21^{\text {st }}$ century audience.

She writes extensively in the preface about the strategies of her research activities that preceded the publication of the other work, Iron Curtain: The Crushing of Eastern Europe, 1944-1956. The scales of this work favoured the study of the archives of many organizations in many countries and interviews with eyewitnesses to the devastating post-war period of Stalinism. But this was no longer journalistic activity. Only formally and schematically can such interviews be classified as genre of journalism. Mastering journalism techniques has served as a tool in research work. A. Applebaum summed up strategic intentions on the subject of her book as follows: "Above all, I sought to gain an understanding real totalitarianism - not totalitarianism in theory but 
totalitarianism in practice - and how it shaped the lives of millions of Europeans in the twentieth century" (Applebaum, 2017: 28). In these words is the key to understanding her identity. The area of A. Applebaum's academic research is between the issues of otherness, the desire to return to intellectual use part of the historical truth of the European nations, and to draw the world's attention to the unknown but open past, reread by her through the pages of Central and Eastern Europe's history.

In this book A. Applebaum mentions examples of the influence of pro-Soviet Western intellectuals on society, starting with Walter Duranty, "who had notoriously (and knowingly) failed to report the existence of mass famine in Ukraine" (Applebaum, 2017: 71), and culminating with Jean-Paul Sartre. She draws attention that "communism ever acquired a certain avant-garde cachet among nihilist, existentialist, or otherwise alienated intellectuals. The towering intellectual figure of the period, Jean-Paul Sartre, was an enthusiastic fellow traveller. Yet even he could never force himself to dwell too much on the Soviet regime's brutality" (Applebaum, 2017: 84). In another chapter, A. Applebaum writes, "The communists also had a claque of influential supporters in the West, among them intellectual luminaries such as Jean-Paul Sartre and Pablo Picasso, who gave a sheen of legitimacy to communist ideology and made many Eastern Europeans feel they weren't merely Soviet subjects but rather part of the Continental avant-garde" (Applebaum, 2017: 436). She finds ambiguous explanations for this phenomenon in several positions: the communist rulers of the Soviet bloc countries had attractive rhetoric, specialists from the Soviet Union, who were educated and knowledgeable of European languages, science and culture, were engaged in the conquest and Sovietisation of creative unions; the creative intelligentsia avoided in every way direct glorification of the regime in every possible way, using various methods of allusions, hints, and unspoken words in their works.

Subsequently, Tony Judt tried to justify in a conversation with Timothy Snyder the "unforgivable confusion" of J.-P. Sartre. Tony Judt noted that Jean-Paul Sartre belonged to the generation of Hannah Arendt, Arthur Koestler, and Raymond Aron. They were "the most influential intellectual cohort of the century" (Judt, Snyder, 2019: 52). After World War II, "they exercised precocious intellectual and literary influence, dominating the European (and American) scene for decades to come" (Judt, Snyder, 2019: 52). T. Judt wondered why French intellectual J.-P. Sartre "so insistently refuse to discuss the crimes of communism" (Judt, Snyder, 2019: 52). While wondering he found a slight double justification for Sartre's behaviour. Perhaps we should stop hoping for the total objectivity of intellectuals' assessments. They are part of the people who gave birth to and shaped them. There are spectra of positive and negative in their behaviour. It is all the more difficult in the $21^{\text {st }}$ century to seek the truth in their actions and judgments. Modernised Europe has long understood those whose intellectual courage was inferior to political expediency under survival. And in the dialogue with the past, research discourse of the humanities scholars who are able to analyse skilfully the individual in the context of its epoch, won. In our opinion, this cohort of researchers includes Anne Applebaum, Timothy Snyder, and Serhii Plokhy.

Like A. Applebaum, the historian Norman Davies, whose views on the division of Europe were part of our earlier study (Nosova, 2018: 135), describes the consequences of the division of Europe. Generalized characteristics of how in the times of 
two world wars, "Europe took leave of its senses" (Davies, 1996: 897), can be found in his work, Europe: A History. The relevant chapter has two titles: Tenebrae (i.e. Darkness, Twilight) and Europe in Eclipse, 1914-1945 (Davies, 1996: 897). The historian regrets the loss of European values: "Of course, seventy years of totalitarian Soviet rule built huge mental as well as physical curtains across Europe" (Davies, 1996: 12). According to the study by N. Davies, under the manipulative influence (eclipse) were representatives of the most educated elite of European states (Nosova, 2018: 135). Some French and German intellectuals were sympathetic to the USSR. They were not outraged by the actions of Stalinism and fascism. N. Davies characterizes emotionally the challenges of that time: "Such was the distortion of worthy ideals that there was no shortage of intelligent men and women who felt compelled to fight 'the War to end War', to join the fascists' genocidal crusade for rescuing 'European civilization', or to excuse the communists' pursuit of peace and progress through mass murder" (Davies, 1996: 899).

Interesting are the discussions around N. Davies' book Europe. A History. T. Judt called him "the prolific historian and apologist of Poland" (Judt, Snyder, 2019: 246). But in his review for The New Republic, T. Judt criticized the book by N. Davies (Judt, Snyder, 2019: 246). Later, they exchanged letters with a slight flare of reproach. They finally reached an understanding after N. Davies "contributed to The Guardian a generous and insightful review" (Judt, Snyder, 2019: 247) of T. Judt's Postwar: A History of Europe Since 1945. It is worth noting that N. Davies and T. Judt analysed Central and Eastern Europe as part of Western Europe. Both scholars warned against considering divisions of Europe after World War II from the standpoint of one side only, i.e. deprived and sacrificed. Their assessments of European intellectuals sometimes were different. A. Applebaum's views on the deeds of individual intellectuals were usually neutral. She was interested in their polemical ideas. This follows from the text of her work Iron Curtain: The Crushing of Eastern Europe, 1944-1956. In our view, she takes into account the fact that European intellectuals after the World War II witnessed and participated in major geopolitical and ideological changes. The interpretation of the concept of "good" and "evil" has changed. This was an ideological distortion due to Sovietization. Therefore, from the perspective of the present, A. Applebaum is cautious about the various "mistakes" of the elites. It does not matter who it is: JeanPaul Sartre, Wisława Szymborska, Milan Kundera, etc. Her analysis of the situation of elites in Central and Eastern Europe after the World War II does not end with a diagnosis. The indisputable truth about those times did not exist and does not exist. A person who interprets social change under the influence of primary or acquired identity sees the surrounding space as a place of survival. And survival involves compromises. After leaving the communist system, the heroes and antiheroes of A. Applebaum's story changed their markers of identity. She presents their changes concisely and elegantly.

Describing the activities of the new regimes after World War II in the countries of Eastern Europe, which came under the influence of the Soviet allies, A. Applebaum, like no other, draws attention to the situation of the church: "From the earliest days of Soviet occupation, the church has been subject to harassment, and worse. Religious leaders, as prominent and influential members of civil society, had been among the first victims of the Red Army's initial wave of violence" (Applebaum, 2017: 295). She 
managed to combine secular history with religious history and to uncover the process of destruction of religious institutions and communities during the so-called "conversion" of Catholic clergy to the communist ideology (Applebaum, 2017: 315).

Józef Tischner, a Polish priest and philosopher, said: "Truth matures in time and through time" (Michnik, Fr. Tischner, Żakowski, 2013: 69). These words referred to different approaches to understanding history. A long time passed between the events: the post-war persecutions and bans imposed on the Catholic Church, and the publication of Karol Wojtyła's book Love and Responsibility (1960). Over these years morality and religiosity proved not to be destroyable entirely by any of communist orders. On the other hand, J. Tischner said ironically that "The party did not need priests with doctoral degrees" (Michnik, Fr. Tischner, Żakowski, 2013: 75). However, the truth has matured over time, confirming vital and constructive role of the church in the life of Polish society. We assume that A. Applebaum depicted functioning of religious institutions in the communist states in view of all these facts.

Another researcher, Piotr S. Wandycz, argues that attacks on churches in Czechoslovakia and Hungary were more brutal than in Poland (Wandycz, 2004: 308). The Polish church was able to resist the onslaught of Stalinism due to the important role of its leader. "The situation in Poland differed insofar as the church was stronger, and primate, Cardinal S. Wyszyński, was a man of great calibre who knew how to combine a rigid adherence to principle with flexibility of tactics," P. S. Wandycz concluded (Wandycz, 2004: 308).

The content of the work, Iron Curtain: The Crushing of Eastern Europe, 19441956, demonstrates the wide range of social problems that the new authorities have created everywhere, "if the immediate postwar period had been characterized by violent attacks on the existing institutions of civil society, after 1948 the regimes began instead to create a new system of state-controlled schools and mass organizations which would envelop their citizens from the moment of birth" (Applebaum, 2017: 342). The reviewers consider this book to be objective and very valuable, thanks to the author's ability in archives, interviews, articles, and memoirs to recreate the realities of the behaviour of those who positively perceived communist regimes, as well as sceptics.

In Iron Curtain: The Crushing of Eastern Europe, 1944-1956, A. Applebaum covered important events of World War II. She devoted three emotional pages to the Warsaw Uprising. In her text there is a succinct mention on how Stalin forbade Allied planes to help the insurgents and stopped Soviet troops on the outskirts of Warsaw. Allied diplomats negotiated unsuccessfully to help Warsaw insurgents from the Poltava air base. Later, Soviet archives of World War II were opened in independent Ukraine. And the fact of the fall of the Warsaw Uprising was revealed to historians in an additional light. Ukrainian historian S. Plokhy twice referred to this page of World War II in his books, Yalta. The Price of Peace and Forgotten Bastards of the Eastern Front. Based on new archival data, S. Plokhy emphasized that it was after the refusal to save Warsaw citizens and the city when the Allies realized how the Soviet government could ignore cooperation, having exhausted the credit of trust. He explained this during the Online Seminar, Forgotten Bastards of the Eastern Front: Ukraine in World War II, held on Facebook on August 26, 2020 by the Fulbright Program in Ukraine and the charity organization, Ukrainian Fulbright Circle, within the project 1945-2020. The 
Price of Peace. End of World War II. On the Occasion of the 75th Anniversary (Online Seminar, 2020). S. Plokhy expressed the opinion that differences in the activities of the Allies emerged during prohibition on the assistance to Polish insurgents by U.S. pilots based at Poltava airport. The betrayal of the Allies' intentions by the Soviet military leaders, led by Stalin, was noticed by U.S. diplomats and pilots.

S. Plokhy and A. Applebaum approached the topics of the Warsaw Uprising and the Yalta Conference differently, but both researchers focused on the fate of the people. A. Applebaum's narrative is based on the opinion of Polish historian Andrzej Friszke, who indicates the emergence of a crisis of confidence to the West and "a sharp realization of the country's dependence on Russia" (Applebaum, 2017: 130) after the Yalta meeting of the Allies. Disappointment and depression resulted from the behaviour of Soviet Army in Eastern Europe grew with the appearance of the documents of the Yalta Conference. A. Applebaum notes that the meeting "was understood, then and later, as a Western betrayal" (Applebaum, 2017: 130). It became obvious to S. Plokhy that during the Yalta Conference the great powers decided the fate of the smaller states without their participation. He believes that there has not yet been a final division of the world. This happened at the Potsdam Conference. In the introduction to his book, Yalta. The Price of Peace, S. Plokhy notes: "Yalta was an important step on the road to that divided and dangerous world, but it did not cause the Cold War or make it inevitable. The Cold War came later, as a result of decisions made by individuals many of whom, at least on the Western side, never set foot on Crimean soil" (Plokhy, 2019: 43).

We found it necessary to compare how A. Applebaum and S. Plokhy studied certain historical events. They achieve results with different stylistic features. Strategically, their texts are future-oriented. A new reading of the historical past becomes a revelation for contemporaries. Large states are guarding their interests even now at the cost of smaller ones. But they no longer dare to discuss the fate of other nations without their participation.

In Iron Curtain: The Crushing of Eastern Europe, 1944-1956, the theme of the Polish military elite and the guerrilla movement is revealed on the basis of archival materials. This provides a conviction to interpret the events surrounding the arrest and repression of the top leadership of the Home Army (Armia Krajowa). A. Applebaum writes how repressive measures were carried out by the secret services of the Soviet Union together with the Polish secret services after the liberation from the Nazis. She explains the methods used by the Soviet Union to introduce the communist regime in post-war Poland. The brutal punitive measures of the Soviet military set Polish society against the communist authority. A. Applebaum illustrates the events of the partisan struggle of Polish patriots by mentioning the outstanding film Ashes and Diamonds, by Andrzej Wajda, which highlighted "the ambiguity of this moment" (Applebaum, 2017: 136).

The military tribunals of the Red Army operated for several years without lawyers and witnesses, writes A. Applebaum. And the Russians in the territory of the Soviet occupation zone used ten camps i.e. prisons (Applebaum, 2017: 138, 139). According to her, the destruction of the military elite in Poland, the youth "werwolfs" in Germany, as well as the chaotic arrests of Hungarians were carried out in support of the Soviet policy of intimidation. Later, the Communists in Eastern Europe began to 
control the activities of the secret services of their countries. In this way, they provided their great political influence. A. Applebaum analysed documents related to the terrorist destruction of the political elite, arrests of Nazi collaborators, and torture of accidental innocent witnesses. Communist governments in these European countries thus showed loyalty to Soviet partners and demonstrated to society "what kinds of behavior and what kinds of people were no longer acceptable in the new regime" (Applebaum, 2017: 148). Another of her conclusions concerns the nature of the behaviour of the communist parties in Eastern Europe that disguised their ties to the curators of the USSR, albeit following their instructions.

We should also pay attention to the explanation of A. Applebaum why she, for example, wrote a book, Red Famine: Stalin's War on Ukraine, about the Holodomor (man-made Famine) of 1932-1933 on Ukrainian territory (Applebaum, 2017). In an interview with Ukraina Moderna magazine, she said: "For me, this work is an attempt to explain Ukraine to the Western audiences. At present, Ukraine plays a very important political role and I want people in the West to understand what exactly happened in Ukraine, why today, in 2018, everything is so and not otherwise" (Mattingly, 2018). These are very important words for our research. A. Applebaum showed publicly what is already known by scientists in Central and Eastern Europe. They first have to explain to Western Europe and to the United States what their countries are, and why and for whom their research on their history, historical memory, and identity are done. And how important all this is, despite the uncertainty and sometimes exoticism.

Here we must refer to Leonidas Donskis' interpretation of György Schöpflin's article on "the discursive handi-cap of Central Europe and the disparity of the linguistic and cultural voices of West and Central Europe" (Bauman, 2013: 165). L. Donskis, talking to Zygmunt Bauman, calls it narrative and interpretation flaws, "Central and Eastern Europe's lack of strategy in the area of the humanities" (Bauman, 2013: 167). He explains this situation with the example of how difficult is to "get a senior post at a French university" (Bauman, 2013: 166), if you are not French, although you have a perfect command of the subject and are extremely well prepared by your academic background. And he emphasizes: "This is so, since you are a non-person in the quick identification system which is part of the mass narratives in the West" (Bauman, 2013: 166). Instead, a Western scholar will always be welcomed at a Central or Eastern European university. L. Donskis sharply assesses this state of affairs: "If we don't reverse this situation, we will be at risk of self-inflicted intellectual and cultural colonialism"(Bauman, 2013: 167).

Therefore, A. Applebaum's strategy to "explain Ukraine to the Western audiences" through a book about the Holodomor in Ukraine synchronises her actions with world public intellectuals, for example, with L. Donskis, S. Plokhy, Z. Bauman, T. Snyder. Her works: Red Famine: Stalin's War on Ukraine (the Duff Cooper and the Lionel Gelber Prizes); Gulag: A History (the Pulitzer and the Duff Cooper Prizes); Iron Curtain: The Crushing of Eastern Europe 1944-1956 (Duke of Westminster's Medal for Military Literature and The Cundill History Prize) are attempts to bridge intellectual and cultural gaps in the important history of Europe as a whole. This position, which was formed by prominent scientists, influenced the strategy of choosing the purpose of her studies. 
For Ukrainian Holodomor researchers, the work of A. Applebaum did not add a new discovery. Some of them made serious factual remarks. In particular, historians Vasyl Marochko and Volodymyr Serhiychuk doubt her position on the number of casualties, the duration of the famine, and the limitation of the number of executors of Stalin's order. They believe that A. Applebaum repeated the figures of population losses, which were named by the Italian historian, A. Graziosi. In fact, she thanks A. Graziosi in the preface and refers to several of his works (as it was mentioned in the former part of this article).

It is worthy of note that the topic and definition of the Holodomor are interpreted differently among Ukrainian researchers and among foreign scholars as well. Timothy Snyder, for example, explains his refrain from using the term "Holodomor" "because it is unfamiliar to almost all readers of English" (Snyder, 211: 412). T. Snyder's monograph, Bloodlands: Europe between Hitler and Stalin, having many polemic and controversial statements, also provoked mixed reactions from Ukrainian historians who study this period. These academic debates cannot overshadow the importance of this monograph for understanding the Ukrainian tragedy in the English-speaking world. A. Applebaum also notes this: "Snyder's ambition is to persuade the West - and the rest of the world - to see the war in a broader perspective." So she wrote in an article for The New York Review of Books, calling T. Snyder's research "a brave and original" (Applebaum, 2010). However, in the scientific discussion of the Polish historians' environment on the text of T. Snyder's book, there is a number of significant remarks that were not heard in the Ukrainian audiences. In particular, Stanisław Jankowiak believes that the American historian presents "a somewhat simplified version of international relations" (Jankowiak, 2011: 121). And it is difficult to deny such a remark. Other participants in the historical debate held at the Adam Mickiewicz University in Poznan emphasized the communicative properties of the text and its approximation to the language of the media, i.e. the partial tabloidization of this topic.

The website of the National Museum of the Holodomor-Genocide in Kyiv contains a detailed review on A. Applebaum's book, Red Famine: Stalin's War on Ukraine, written by the museum director, Olesya Stasyuk. It contains a number of thorough remarks on the "misrepresentation of historical facts." Despite the critical remarks, historian O. Stasyuk believes that "in addition to purely academic research, such scientific and journalistic works are needed, which will make this topic a top-notch issue of world and civilizational scale, which should be spoken and remembered not only by Ukrainians but also by ordinary people all over the world in order to do right conclusions and prevent the emergence of such crimes in the future" (Stasyuk, 2018). According to the historian, former director of the Ukrainian Institute of National Remembrance, and current member of Parliament of Ukraine Volodymyr Viatrovych: "There is nothing wrong with the fact that A. Applebaum's book, written in an interesting and talented way, provokes discussions. Ultimately, this means that this topic continues to concern both scholars and the public. [...] It seems to me that some reviews which have appeared in Ukraine are critical of A. Applebaum's book, sinning with excessive emotionality..." (Shchur, 2018).

If we compare A. Applebaum's study with T. Snyder's work on the same topic, her style of writing is different, although it is also quite clear to readers from outside the 
academic world. But we do not have to blame her for less use of archival sources or manifestation of her own position on the debatable historical facts. What these public intellectuals have in common is a thorough theoretical training, an interest in the European history of the $20^{\text {th }}$ century, and a noble goal, which is to develop an academic career by studying Central and Eastern Europe. As a result, it gave them the opportunity to become authors of valuable works that strategically open pages on the intellectual discourse from a large part of the European continent, unknown earlier to the Englishspeaking world.

In their academic paradigms, the concept of identity has a multidimensional structure. The identity of the nations whose history they are studying has not been stable; it has been fluid, changing, especially among the ruling elite. Our task is not to give a comprehensive explanation of the philosophical aspect of the identity within postmodern discourse. But during the period of Sovietisation of Eastern Europe, changing identities coexisted. This is shown by A. Applebaum, especially in the chapters dealing with the education, culture, and religion of Poland, Hungary, and the Czech Republic in the work, Iron Curtain: The Crushing of Eastern Europe 1944-1956. Her "otherness" makes her possible to impartially analyse the national and cultural changes in the post-war history of the peoples enslaved by the communist regimes. This conclusion also applies to her book on the Holodomor in Ukraine. She paid more attention to the perpetrators' extermination acts toward people in some villages and towns, while distantly interpreted the concept of genocide.

The value of A. Applebaum's books is that she manages to write about the "painful pasts of Europe" (Mink, Neumayer, 2007) without politicization. Her works carry knowledge of the past. This knowledge is directed to the future. They open a dialogue between generations. They stimulate thinking about historical truth. The content of books about the Holodomor in Ukraine and Stalin's Iron Curtain in Europe correspond to the modern understanding of long-standing historical events.

A. Applebaum also draws attention to the formation of national and cultural narratives by scholars, writers, journalists, and actors, directors who understood the shortcomings of communist ideas. They experienced part of the events described by the author: someone was repressed in their country, someone was forced to emigrate, and someone tried to create within the framework of social realism (Applebaum, 2017: 408). For example, Andrzej Wajda, Bertolt Brecht, Wisława Szymborska, Max Lingner, and Milan Kundera belong undoubtedly to the group of public intellectuals who bear witness to that time (despite the fact that their biographies remain not free from controversies). Not all of their works equally imprinted the changes after World War II. A. Applebaum's narrative on the situation of European intellectuals after World War II gives rise to our further research on this topic started earlier (Nosova, 2018: 134). Thus, The Tragedy of Central Europe is about how the states at the centre were affected: "the drama of Europe has been concentrated there." (Kundera, 1983). The new geopolitics dictated to these countries the forgetting of their own identity and inclusion in the processes of Sovietisation (Nosova, 2018: 134). In this article, M. Kundera briefly analyses the impact of previous traumatic events: the great Hungarian revolt, the occupation of Czechoslovakia, and the Polish revolts. M. Kundera connects the origin of these traumas with Soviet Russia (Nosova, 2018: 134). He writes that the threats 
from the policy of Sovietisation had a dramatic effect on the changes in the identities of many nations of the USSR: "Indeed, nothing could be more foreign to Central Europe and its passion for variety than Russia: uniform, standardising, centralising, determined to transform every nation of its empire (the Ukrainians, the Belarusians, the Armenians, the Latvians, the Lithuanians, and others) into a single Russian people (or, as is more commonly expressed in this age of generalised verbal mystification, into a "single Soviet people")." (Kundera, 1983).

It is clear why A. Applebaum deeply analyses the activities of European artists at the era of "High Stalinism" (Applebaum, 2017: 407). Collective cultural memory, the identity of the nation, the identity of civilisation - the explanation of these narratives structures the problems of Central Europe that arose after the divisions caused by World War II. The philosophical thought of some post-war works was aimed at finding explanations for what intellectuals still cannot find now: why Western Europe betrayed Central Europe, why its abduction was allowed, i.e. the destruction of culture, and the ruination of collective memory. Criticism of the Western intelligentsia, which in the everyday context of brutal events showed agreement with the authorities of first the Nazis and then the Communists, is now reflected in the media, books, and research. Historians A. Applebaum and T. Snyder recorded such facts, based on archival sources, and on the works of national scholars, published in different languages.

In the works of A. Applebaum, as well as T. Snyder, S. Plokhy, and N. Davies, we can see another important discursive value: in the assessments of that time, they help to overcome the outdated ideological and matrix approaches, used by certain circles of Ukrainian experts. Due to the widespread influence of Russian and former Soviet discourse, scholars and journalists from Ukraine continue to experience difficulty in finding their own perspective on retransmitting the past in the $21^{\text {st }}$ century.

We can assume that A. Applebaum in her style of historical writing reflects the new modern practice of presenting history. Prominent world's scholars Jerzy Topolski, Hayden White, Frank Ankersmit, and Ewa Domańska drew attention to the importance of a qualitative historical narrative as a "result of a historian's work" (Topolski, 2012: 22).

In A. Applebaum's pathway, journalism and writing exist in parallel, but complement each other. Journalism and a good education provided her an opportunity to build a strategy for writing and research. Her interest in global changes in Central and Eastern Europe in the 1990s, the existence of people in those changes, and the opening of the Holodomor, the tragedy of the Ukrainian people, to Western readers, brought her great success and numerous awards. A. Applebaum's books also had critical remarks, but they did not lead to a defeat in her creative intentions. She announces her activities and plans on her Facebook page, in many interviews, and through a personal website.

In our opinion, to understand the painful past, every nation must also have in the scientific arsenal the view of "outside" researcher, the translator. Transnational impartiality and open-mindedness, other scholarly traditions with a deep understanding of the identity of the reserched participants in historical processes - provide an opportunity to direct readers' attention to the "other" view in the culture, history, and social development of different peoples and countries. A. Applebaum's interest in Central and Eastern Europe brought her closer to an "other" identity. For readers, the narra- 
tives expressed in the books are perceived clearly: as a discovery, as a promotion, and as a disturbingly fascinating text. For the historians, with the identity of European nations, some conclusions in her books are debatable, and her interpretations are sometimes contradictory; however, such remarks are leveled during academic conferences or published in professional academic journals. They do not contradict her important achievement - to raise in the English-speaking world the unknown European part of history.

It is worth paying attention to the formation of national and cultural meanings by intellectuals, which include A. Applebaum, as well as scholars, writers, and journalists who have studied the historical memory of other peoples. This category of educated people manages to break some of the problems of silence European history. They keep the existential link between the generations, between the heroes of their books and the readers.

\section{REFERENCES}

Ankersmit F. R. (1983), Narrative Logic: A Semantic Analysis of the Historian's Language, Martinus Nijhoff Publishers.

Applebaum A. (1994), Between East and West: Across the Borderlands of Europe, Pantheon Books.

Applebaum A. (2017), Iron Curtain: The Crushing of Eastern Europe, 1944-1956, Mohyla Academy Publishing House, Kyiv (In Ukrainian).

Applebaum A. (2017), Red Famine: Stalin's War on Ukraine, Penguin Random House.

Applebaum A. (2010), The Worst of the Madness, “The New York Review of Books”, Vol. 57, https:// www.nybooks.com/articles/2010/11/11/worst-madness/.

Bauman Z., Donskis L. (2013), Moral Blindness: The Loss of Sensitivity in Liquid Modernity, Polity Press.

Davies N. (1996), Europe: A History, Oxford University Press.

Domańska E. (2012), Historia a wspótczesna humanistyka: studia z teorii wiedzy o przeszłości, Wydawnictwo K.I.S. (In Ukrainian).

Graziosi A. (2001), Guerra e rivoluzione in Europa, 1905-1956, Il Mulino.

Jankowiak S. (2011), Polska na styku XX-wiecznych totalitaryzmów. Debaty Historyczne. Dyskusja panelowa. Debata o książe Timothy Snydera pt.: Skrwawione ziemie. Europa między Hitlerem a Stalinem (przeł. B. Pietrzyk, Świat Książki, Warszawa 2011, s. 544) (Stanisław Jankowiak, Jakub Wojtkowiak, Violetta Julkowska, Maciej Bugajewski), “Sensus Istoriae”, Vol. V (2011/4).

Judt T., Snyder T. (2019), Thinking the Twentieth Century, Choven Publishing House (In Ukrainian).

Kundera M. (1983), Un Occident kidnappé ou la tragédie de l'Europe centrale, "Le Débat", No. 27.

Mattingly D. (2018), Anne Applebaum "Readers in the West will read my book on the Famine of 1932-1933, and it will help them better understand the current situation in Ukraine", https:// uamoderna.com/jittepis-istory/anne-appelbaum (In Ukrainian).

Michnik A., Fr. Tischner J., Żakowski J. (2013), A Talk Between a Citizen and a Priest [Miedzy Panem a Plebanem], Dukh i Litera (In Ukrainian).

Mink G., Neumayer L. (2007), L’Europe et ses passés douloureux, La Découverte. 
Nosova B. (2018), Komunikatywna filozofia J. Habermasa: ekstrapolacja w dyskursie medialnym, "Komunikacja i Konteksty", No. I, Wydawnictwo im. Stanisława Podobińskiego Uniwersytetu Humanistyczno-Przyrodniczego im. Jana Długosza w Częstochowie (In Ukrainian).

Online Seminar (2020), Forgotten Bastards of the Eastern Front: Ukraine in the World War II, Kyiv, https://www.facebook.com/507401809367521/videos/1505272969674510/ (In Ukrainian).

Plokhy S. (2019), Yalta. The Price of Peace, Klub Simeynoho Dozvillya (In Ukrainian).

Shchur M. (2018), I Have Always Considered the Holodomor a Genocide - Anne Applebaum, https:// www.radiosvoboda.org/a/29490401.html (In Ukrainian).

Snyder T. (2011), Bloodlands: Europe between Hitler and Stalin, Random House.

Snyder T. (2003), The Reconstruction of Nations: Poland, Ukraine, Lithuania, Belarus, 1569-1999, Yale University Press.

Stasyuk O. (2018), Review on Anne Applebaum's Book “Red Famine: Stalin's War on Ukraine”, https://holodomormuseum.org.ua/en/news-museji/review-by-olesya-stasyuk-on-anne-applebaum-039-s-book-red-famine-stalin-039-s-war-on-ukraine/.

Titscher S., Meyer M., Wodak R., Vetter E. (2000), Methods of Text and Discourse Analysis: In Search of Meaning, SAGE.

Topolski J. (2012), Jak się pisze i rozumie historię. Tajemnice narracji historycznej, Wydawnictwo K.I.S. (In Ukrainian).

Wandycz P. S. (2004), The Price of Freedom: A History of East Central Europe from the Middle Ages to the Present, Krytyka (In Ukrainian).

White H. (1966), The Burden of History, "History and Theory", Vol. 5, No. 2.

\begin{abstract}
The text aims to present the strategy used by Anne Applebaum to bring the history of Central and Eastern Europe closer to western audiences. In the article, the author was presented as a journalist and public intellectual who developed an original way of speaking and writing about the past of Central and Eastern Europe. She has been portrayed as a kind of mediator who attempts to explain the essence and sources of the diverse identities and narratives that have formed among the nations and cultures of Central and Eastern Europe. Selected assessments of her activity, formulated by historians as well as public opinion leaders, were also presented.
\end{abstract}

Keywords: strategy of building a historical narrative, telling the past of Central and Eastern Europe in the West, Central and Eastern Europe, Anne Applebaum, public intellectuals

\title{
HISTORIA STOSUNKÓW MIĘDZYNARODOWYCH W EUROPIE CENTRALNEJ I WSCHODNIEJ - STRATEGIA NARRACYJNA ANNE APPLEBAUM
}

\section{STRESZCZENIE}

Celem tekstu jest prezentacja strategii, w oparciu o którą Anne Applebaum stara się przybliżać zachodniemu odbiorcy historię Europy Centralnej i Wschodniej. W artykule autorka przedstawiona została jako dziennikarka i intelektualistka, która wypracowała oryginalny sposób mówienia oraz pisania o przeszłości Europy Środkowej i Wschodniej. Ukazano ją jako swoistego mediatora, który usiłuje wytłumaczyć istotę oraz źródła różnorodnych tożsamości oraz 
narracji ukształtowanych wśród narodów i kultur Europy Centralnej i Wschodniej. Przedstawione zostały także wybrane oceny jej aktywności, prezentowane zarówno przez historyków, jak i opinię publiczną.

Słowa kluczowe: strategia budowania narracji historycznej, opowiadanie przeszłości Europy Środkowej i Wschodniej na Zachodzie, Europa Środkowo-Wschodnia, Anne Applebaum, intelektualiści publiczni 
